\title{
Vernomimicry: Bridging the Gap between Nature and Sustainable Architecture
}

\author{
Ahmed Khoja ${ }^{1} \&$ Sahl Waheeb ${ }^{2}$ \\ ${ }^{1}$ Munich University of Applied Sciences, Germany \\ ${ }^{2}$ Department of Engineering Science, Community College, Umm AlQura University, Saudi Arabia \\ Correspondence: Sahl Waheeb, Department of Engineering Science, Community College, Umm AlQura \\ University, Saudi Arabia. E-mail: sawaheeb@gmail.com
}

Received: March 7, 2019

doi:10.5539/jsd.v13n1p33

\begin{abstract}
Biomimicry or learning from nature in architecture is a method that aims to develop a sustainable design solution for modern world challenges by mimicking models, systems, and elements of nature. However, developing biomimetic solutions is not a problem-free approach due to the fact that both, biology and architecture are different. Therefore, the vernacular architecture being the human form of natural construction can be used to help bridge the gap between nature and architecture. There are certain potentials and limitations of using both, biomimicry and vernacular architecture in modern day architecture. However, several methods and the process can be used to develop solutions for these issues. A fusion between both approaches in the form of "Vernomimicry" be used to apply nature based and nature like solutions in architecture successfully.
\end{abstract}

Keywords: vernomimicry, architecture, nature, biomimicry, biology

\section{Introduction}

From Stockholm conference in 1972 to Kyoto Protocol in 1997; to Johannesburg Declaration on Sustainable Development in 2002; the world is in a continuous search to find solutions for the environmental crises (Singh, 2016). Although, globally, the best approach to sustainability is debatable; however, there is a growing consensus for discovering new ways that can assist in eradicating the hardships (UN, 2012). This notion is also relevant in the field of construction and architecture, where the shift to an environmentally conscious approach became inevitable in the last decade. The pursuit of sustainable design and environmentally friendly construction through different approaches has attained vital importance. Along with it, the construction industry consumes about three tones of the raw material where fifty percent of the raw material is derived from nature. It also consumes forty percent of energy and produced a total of 50 percent waste (Zillante et al., 2013). The consumption of a large amount of energy also stresses its utilization of sustainable practices. One of the new rising and most promising approaches that aim to tackle the sustainability dilemma can be found in the "biomimicry" or "learning from nature" approach (Amer, 2019). This approach considers nature as a source of ideas and inspirations instead of just a source of goods (Blok, and Gremmen, 2016). Also, this will help in overcoming the wastage of the resources accounting to the universal truth of limited natural resources. Using biomimicry in architecture is still a relatively new approach due to the fact that biology and architecture are two different spheres.

Therefore, there is a need for a medium of transfer that transfers the idea from one "bank" (nature) to another "bank" (architecture). The main question arising here is;

- What sort of medium can be used to transfer these ideas?

- Can vernacular architecture being natural and native human construction help to bridge the gap between nature and architecture?

- If yes, can it then present a missing link?

Reflecting on these primary questions, other vital issues arise are related to the potentials and limitations of using biomimicry. The above-posed questions present fundamental problems that architects face while dealing with biomimicry. The present study will shed light on the questions as mentioned above and will focus mainly on the discussion of the role that vernacular architecture can play to bridge the gap between biomimicry and 
architecture. The study will be carried out by examining the biomimetic and vernacular architecture approaches as well as the potentials and limitations of each approach. The paper will determine if learning from the vernacular approach - "vernomimicry"- is a viable, applicable tool to reconnect nature and architecture. The study assumes that the findings of the research will assist in devising smart design and forming a connection of the architect designs with the natural environment. The study believes that biomimetic design instigation is said to upsurge and become popular in future architecture design.

\section{Methodology}

The study has adopted an exploratory study design using a qualitative analysis (Creswell, and Creswell, 2017). For this, the study explores the vernacular architecture design and examines how far it is from nature. It explores the design using biomimetic and vernacular architecture approaches from bridging the gap that prevails. Following it, these approaches are examined on the design. The architecture selected for the paper is the Yaama Mosque. The design of the mosque is analyzed in light of its design qualities and nature design principles. The application of these principles addressed the comparison of the approaches in the light of new and old approaches and systematically compared them. This is done to determine the similarities and differences between the architectural components. For establishing a comprehensive documented understanding, the building components are studied in both conventional and contemporary architectural practices. Finally, the study will discuss some of the similar solutions that both nature and vernacular architecture have developed in the areas of materials and energy.

\section{Literature Review}

\subsection{Approaches to Nature in Architecture}

A number of approaches to nature have been used in architecture throughout history (Gruber, 2011). These approaches, aside from biomimicry, can be divided into three main categories: bio-utilization, biomorphism, and biophilia (Pawlyn, 2011). Identifying different approaches can help in clarifying the place biomimetic architecture holds;

1) Bio-utilization describes the direct utilization of nature in architecture for beneficial purposes (Pawlyn, 2011). Use of reed beds as a water treatment system can be taken as one of such examples.

2) Biophilic architecture comes from 'biophilia' - a term that refers to an instinctive bond shared between humans and other living organisms (Wilson, 1984). Biophilia suggests two methods to create biophilic architecture: (1) by including different aspects of nature into a built environment (like trees and shrubs); (2) by copying some structural properties from nature into the built environment (Kahn, 2011).

3) Biomorphism - the use of natural forms in architecture - can be considered as the most widely used approach of nature in architecture. Examples of biomorphism can be found throughout history from the use of the lotus leaves in Egyptian columns (Brown, 1845) in ancient times to Beijing National Aquatic Centre by PTW in 2007. Zoomorphism and anthropomorphism can also be included under the general term Biomorphism.

It is worth noticing that approaches mentioned above and biomimetic architectures overlap in a variety of ways. However, a biomimetic design defers from the approaches mentioned above as it aims to deliver a sustainable function based on a solution found within nature (Pawlyn, 2011).

\subsection{Vernacular Architecture}

Vernacular architecture is a term that is widely used to describe a wide array of architecture such as folk, tribal, indigenous, and traditional architecture (Vellinga, 2017). However, there is no uniformed definition of the vernacular present in the literature (Vellinga, 2017). However, Oliver (2006) in the book "Built to Meet the Needs" gives a remarkable definition of vernacular architecture as "native science of building."

The interest in vernacular architecture goes back to the 18th and 19th centuries. At that time, the study related to vernacular was mainly carried out by antiquarians and architects under the influence of Arts and Craft Movements (Hamard et al., 2016). In the 1960s; however, the interest in the vernacular started to gain greater momentum, not only as a tool to criticize modern architecture but also as a model to create sustainable buildings (Radoine, 2017). Although the study of vernacular architecture in today's time has significantly increased, still the topic occupies a little part in the architectural studies as compared to other fields of architecture (Michael et al., 2017).

Vernacular can be of a great benefit to sustainable architecture. It is defined by Raport (2006), "an unequalled, and only possible, 'laboratory' with a vast range of human responses to an equally vast range of problems; 
cultural, technological, or resources (including materials), site, climate, ways of making a living and so on", which in turn have evolved over a long period of time alike nature.

\subsection{Biomimicry}

The use of nature as a learning source can be traced back in architecture to ancient times. It is noteworthy that ancient architecture has used not only nature to develop biomorphic forms, but also as a source of solutions for technological problems. A remarkable example can be found in Vitruvius's Ten Books on Architecture (Morgan, 2005) stating that "all machinery is derived from nature, and is founded on the teaching and instruction of the revolution of the firmament." This view of nature as a learning source changed in the 17th century by the "father of scientific thought" Francis Bacon during the Enlightenment Era (Foltz, 2003). A large number of scientists, architects, governmental officials, etc. still believes that environmental problems can be solved using technologies and machines (Foltz, 2003; Bob and Jason, 2004). Moreover, they believe that human can exercise even greater dominance over nature and advances in building technologies and materials will result in high building performance and energy consumption (Foltz, 2003; Bob and Jason, 2004). The return to nature as a learning source regained momentum in the middle of the past century with some pioneers; Eero Saarinen and Jørn Utzon. However, their work in the field did not discuss much beyond the biomorphic approach (Petra, 2011) Despite a number of approaches to nature that have evolved over the years; biomimicry appears to be the most suitable one.

Biomimicry relays on a very convincing argument stating that "after 3.8 billion years of evolution, nature has learned: What works. What is appropriate? What lasts" (Benyus, 2002). From this point of view, nature must be treated as a source of ideas that can provide solutions for a variety of human problems. Biomimicry recognizes vernacular architecture as part of nature; however, its use in biomimetic architecture is not fully appreciated (Gruber, 2011). A small amount of contribution has been made regarding implementation of vernacular solutions also regarding discovering a connection between nature and architecture, except for few morphological aspects (Gruber, 2011).

In the present study, the definition of biomimetic architecture or biomimicry in architecture proposed by M. Pawlyn (2011) in the book "Biomimicry in Architecture" is used. Biomimicry, as defined in the book, "mimicking of the functional basis of biological forms, processes, and systems to produce sustainable solutions" (Pawlyn, 2011). It should be noted that biomimetic architecture is a relatively young field and is a part of a larger field of biomimicry or bionics (Gruber, 2011). Both terms (biomimicry and bionics) have emerged during the 1950 s and 60 s and describe the act of learning from nature or producing nature-like functions (Julian et al., 2006).

\section{Comparison between Natural and Vernacular Design Principles: The Case of Yaama Mosque}

\subsection{The Case of Yaama Mosque in Niger: Design Brief}

The village of Yaama is located on the Sahel region of Niger in the rain dependent agriculture area. Yaama falls in the Sudan climatic zone with an average high temperature of $33^{\circ} \mathrm{C}$ in May/April and $23^{\circ} \mathrm{C}$ in December/January. The average rain fall in the area is about $500 \mathrm{~mm}$ and the village experience a humid season of 150 days on an average. To this end, high temperatures in combination with humidity can create uncomfortable climate conditions (The Aga Khan Award for Architecture, 1986).

In 1962, the village of Yaama required a Friday Mosque with a small Mihrab, which was built using local materials and local building techniques. In 1977, the mosque's roof needed major repairs due to the heavy rainfall. For this reason, a dome was proposed, and a major upgrade was commissioned. The mosque by the time of its completion in 1982 consisted of two floors, four large minarets, and a new entrance hall, summing the total built-up area to $500 \mathrm{~m} 2$. The upgrades were made by using local materials, and ventilation was provided through small openings in the walls. The design was awarded the Aga Khan award for architecture in 1986 (The Aga Khan Award for Architecture, 1986). 


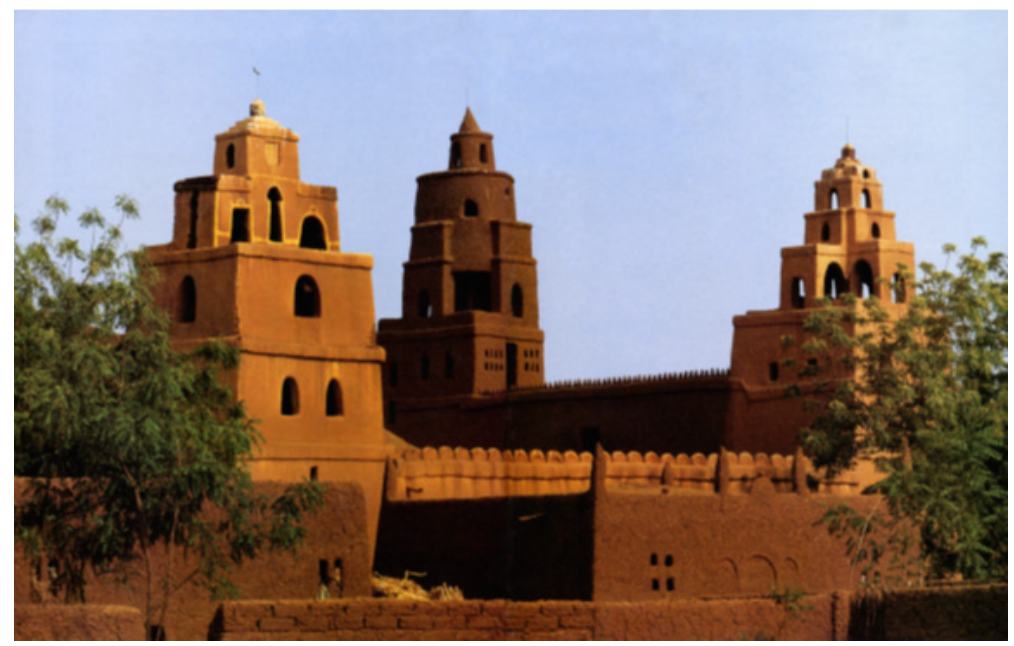

Figure 1. Yaama mosque (Source: Mosque Gallary, 2016)

The mosque was constructed by the help of the community. For example, the land for the mosque was a donation made by one of the villagers, the sun-dried mud bricks were made on site by village men, and water for the mud bricks was provided by the women (The Aga Khan Award for Architecture, 1986).

\subsection{Nature Design Principles and Yaama Mosque: A Comparative Analysis}

The following table presents a comparison between Yaama mosque design qualities and nature design principles. The nature design principles are composed of 2 theoretical works: (1) nature's construction design principles proposed by Nachtigall (1997) and (2) Benyus's (2002) comparison between biological and human-made systems. 1 in the table represents a principle that was implemented in the Yaama Mosque design and $0-$ a missing principle. 
Table 1. Comparison between Nachtigal and Benyus natural design principles and vernacular design qualities found in Yaama mosque

\begin{tabular}{|c|c|c|}
\hline Nature design principles & Yaama Mosque & Description \\
\hline Integrated construction & 0 & The mosque is an additive constriction \\
\hline Optimization of the whole & 1 & $\begin{array}{l}\text { With the renovation of the mosque the } \\
\text { building was optimized as a whole; the } \\
\text { renovation was not focused on maximizing } \\
\text { one aspect. }\end{array}$ \\
\hline Multi-functionality & 0 & Mono-functional \\
\hline Adjustment about the environment & 1 & The mosque is adjusted to its environment \\
\hline $\begin{array}{l}\text { Direct or indirect use of solar } \\
\text { energy }\end{array}$ & 1 & $\begin{array}{l}\text { The mosque was constructed only by natural } \\
\text { materials and human labour (indirect use of } \\
\text { solar energy using metabolism); in operation } \\
\text { the building relay on solar energy (heating, } \\
\text { cooling, and ventilation) }\end{array}$ \\
\hline Temporary limitation & 1 & $\begin{array}{l}\text { Although there is no self-healing process, the } \\
\text { building needs constant care as in other } \\
\text { constructions made by nature. }\end{array}$ \\
\hline Complete recycling & 1 & $\begin{array}{l}\text { The materials that were used in renovating the } \\
\text { mosque are either fully recyclable or recycled } \\
\text { from the old mosque }\end{array}$ \\
\hline Development by trial and error. & 1 & $\begin{array}{l}\text { Traditional techniques have evolved through } \\
\text { "trial and error." }\end{array}$ \\
\hline Closed loop flow of resources & 1 & The building used only local natural materials \\
\hline Regenerative & 0 & The building is extractive \\
\hline No long-term use of toxins & 1 & No toxins were used in the construction \\
\hline Complex & 0 & Simple \\
\hline Adapted to constant change & 0 & The mosque does not adapt to constant change \\
\hline Use local recourses & 1 & Only local recourses were used \\
\hline
\end{tabular}

Table 1 shows that nature and Yaama mosque design met in 9 out of 14 design aspects. This high level of similarity qualifies the vernacular to be a great source of ideas for architecture to produce a nature-like sustainable architecture or biomimetic architecture. These aspects have also been explored in the recent study by Al Tawayha, Braganca, and Mateus (2019) which showed that strategies of vernacular architecture induce in the nature like sustainability which can help progress the architectural design in a more optimized manner.

\section{Processes of Learning and Limitation}

Learning from both nature and vernacular architecture can be done by using different methods such as the use of analogies, inspirations, and abstraction; however, limitations to learn from both vernacular and nature are quite different (Pankina, and Zakharova, 2015). Exploring these limitations would help shed light as which approach is more appropriate to create biomimetic architecture.

\subsection{Challenges Facing the Biomimetic Approach}

Copying of the natural aspects is difficult and somewhat not possible, however, in case some aspects are copied, they are far from the original. The first challenge is to use biomimetic approach to create a nature like architecture for the technology transfer problem from nature to architecture (López, Rubio, Martín, and Croxford, 2017). Architects tend to be pragmatic with the information presented to them by scientists neglecting the life sciences aspect. Gruber (2011) indicates that they try to cut short the information before fully understanding the phenomenon that generates their excitement. For example, in the case of Harare's East Gate Centre by Mick Pearce held as a biomimetic architecture icon, although, it functions in a far different way (Scott and Rupert, 2008). This phenomenon might explain why biomorphism is much widely used among architects as compared to 
biomimicry. Moreover, each time the architects want to apply a biomimetic approach to the problem, they need to start the process from scratch. To this end, this consumes both time and effort; additionally, the results are also not guaranteed (Julian et al., 2006). The third limitation that architects face in biomimicry is that they always need to wait for a biologist to reveal an interesting phenomenon that is useful in architecture.

\subsection{Challenges Facing the Vernomimetic Approach}

The simple act of repeating history contradicts with the very nature of vernacular architecture as the process was a result of an evolutionary process. Two limitations can be identified in the vernacular approach or vernomimicry. The first limitation is referred to the cultural image problem. When an architect tries to provide solutions based on vernacular architecture, the experience shows that he usually gets a negative response from the end user. This problem has also been highlighted by Fisher (2015) who explored the architectural philosophies. The similar situation was observed in the case of Fathy's Braiz and Qurna villages in Egypt. Moreover, also in the case of ADAUA (Association for the Development of an African Urbanism) in Rosso, Senegal (Ozkan, 2006). Both designs were a failure for the users, although, they had used innovative vernacular techniques. To this end, such failures can be attributed to cultural image problems (Ozkan, 2006).

The second limitation that architects face when applying vernomimicry is associated with modernization and globalization (Vellinga, 2006). Vellinga (2006) has argued that the amount of vernacular architecture left in the modern world is relatively small and is rapidly vanishing. This, in turn, leaves architects with a relatively narrow window of "pure" vernacular examples for learning. New examples of vernacular architecture have been infected in one way or another by modernity as visible in the cases of shanty towns all over the world (Fernandes et al., 2017).

\section{Similar Problems, Similar Solutions: Examples from Nature and Vernacular Architecture}

\subsection{Efficiency and Economy in Natural and Vernacular Structures}

Structures in nature follow a simple rule described by Vincent (1986) "materials are expensive, and shape is cheap." Nature aims to build the most effective structure with the most economical use of energy and materials. This generates an optimization process in which trade between energy and function of structure takes place. This optimization process leads nature to reach a balance between used materials and energy, shape, and properties of structures and their function (Wegst et al., 2015). This is the optimization, which is referred to as call efficiency by the experts of physiology (Gosline, 2005). It represents a benefit to cost ratio in nature where the structure ability to support load is compared to the cost to build and maintain the structure (Friedrich, 2016). In the field of structural engineering, the research on optimized structures is always in process (DebRoy et al., 2018). However, few engineers manage to achieve a balance between shape and materials.

\subsection{Abalone Shells and Catalan Vaults}

The Abalones build their ceramic structure of shells by composing calcium carbonates in hexagons to form brick-like tiled structures (Lin, 2005). As displayed in figure 1, these shells enjoy some of interesting properties like self-assembly and self-healing mechanisms (Lin, 2005). More interestingly, these shells are very thin and extremely strong (Pawlyn, 2011). This can be attributed to the optimization process observed in nature between shape, available material, and functions of a structure (Figure 2).

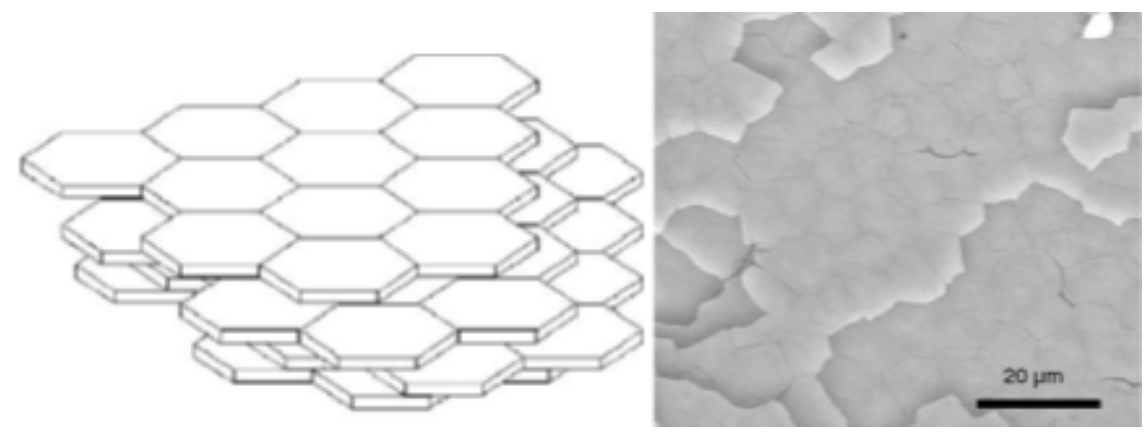

Figure 2. Abalone shell arrangement of tiles (Source: Lin, 2005)

The Catalan vaults are a vernacular technique to build domes and shells by using ceramic tiles resembling Abalone shells. The Catalan vaulting technique uses a multiple layers of ceramic tiles. The first layer is built with a quick-setting mortar (usually gypsum), and then other layers are added over the first one. This results in 
an interlinked composite of bricks that enjoys a good resistance against compression and tension (Anderson and Dieste, 2004). This technique was later developed by Rafael Guastavino in the early 20th century. Guastavino used statics graphic calculations to calculate the absolute minimum amount of materials needed to support the loads within the safety margins (Figure 3). In this way, reliable shells, cheaper and lighter as compared to other roofing methods were built (Anderson and Dieste, 2004).

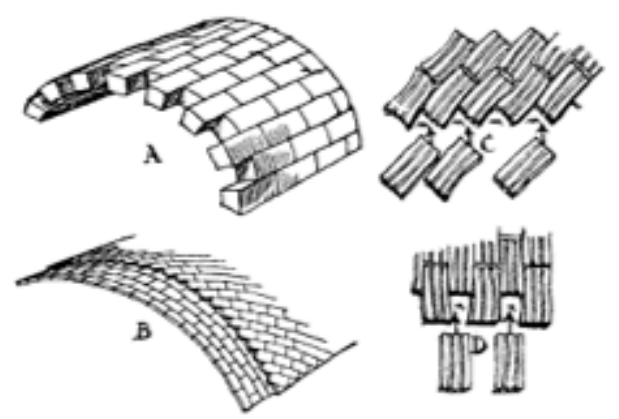

Figure 3. Comparison between stone vaulting (A) and Catalan vaulting (B) (Source: Sijpkes, 2014)

\subsection{Energy Harvesting in Nature and Vernacular Architecture: Thermoregulation}

In nature, a large amount of energy is harvested either directly from the environment or by metabolism to regulate an animal's body temperature (Solomon et al., 2004). Each of the above-mentioned methods of energy harvesting has a great impact on animal behavior, size, and activity. Animals have developed some adaptations to maintain their body heat on the optimal operation level, usually between $30^{\circ} \mathrm{C}$ and $45^{\circ} \mathrm{C}$ (Cossins and Bowler, 1987). Ectothermic animals rely on the energy provided to them from their environment and for this purpose they have developed different strategies to harvest this energy. One of these strategies to maintain body heat is to build nests (Figure 4). Insects maintain the core temperature of their nest through different methods such as nest location, shape, orientation and building material (Cossins and Bowler, 1987).

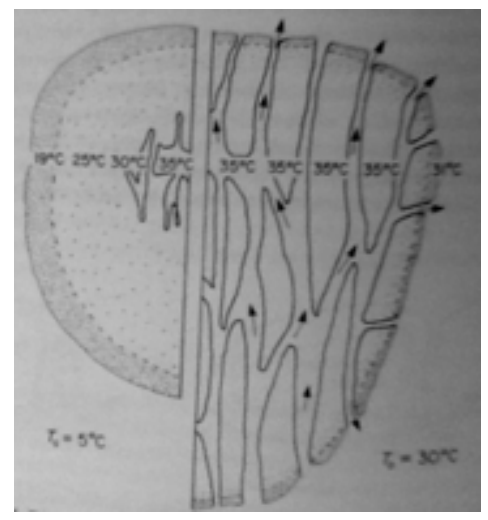

Figure 4. Diagram showing the thermoregulation of a swarm of bees in at low and high temperatures

Humans; on the other hand, have constructed and used shelters throughout history as a part of their temperature control mechanism, although, they maintain their body temperature through metabolism (Toates, 2007). The vernacular architecture is full of successful examples related to adaptations in different climates.

\subsection{Climate Control in Termite Mounds and Vernacular Architecture}

Termites are ectothermic insects and tend to maintain the nest temperature between $29^{\circ} \mathrm{C}$ and $32^{\circ} \mathrm{C}$, which represents termites' preferred temperature zone (James et al., 1994). Termites apply various strategies to maintain the temperature of the nest core between the above-mentioned ranges. The behavior of termites, as well as the climate and available materials, are those elements that affect the shape of the nest (Harris, 1956). Air shafts at the top of the nest as well as the shape, thickness, and openings on the sidewalls of the nest play a decisive role in the ventilation and climate control mechanisms of the nest (Figure 5). However, the exact way of how the above-mentioned ventilation strategies work is still under dispute (Korb and Eduard, 2000). 


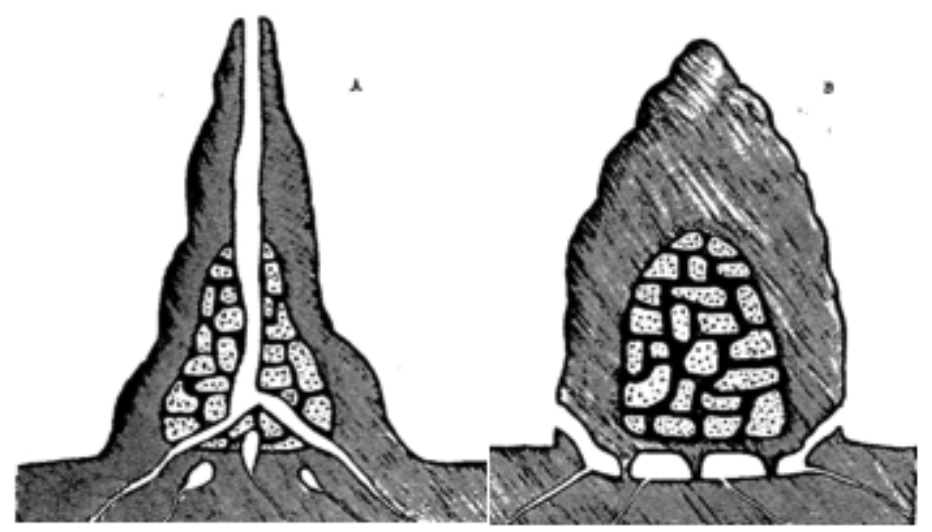

Figure 5. Diagram showing different shapes of termite's mounds (Sources: Harris, 1956)

In the vernacular architecture, a wide array of shapes and a number of different innovative cooling/heating and ventilation strategies were applied to maintain an acceptable indoor climate (Fathy et al., 1986). The vernacular architecture used a wide array of methods to control the indoor climate, such as use of wind captures, wall openings and vents, wall thickness and materials as well as different roof shapes (Allard and Santamouris, 1998). Figure 6 gives an example of a vernacular ventilation method in hot dry climates.

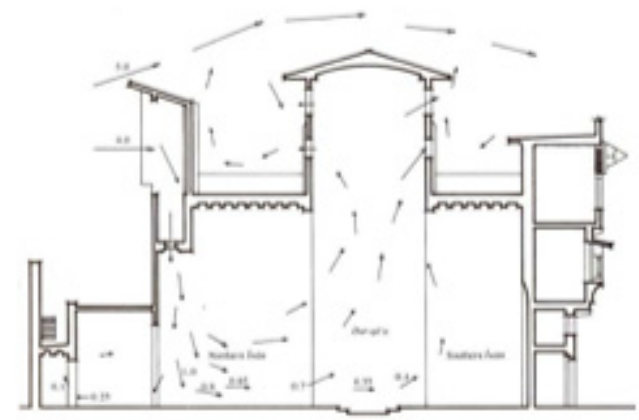

Figure 6. Section of a vernacular house in Cairo showing how the wind catchers "Malqaf" and the wind escape vents produce internal air movement (Source: El-Borombaly, and Molina-Prieto, 2015)

In 1964, an experiment was carried out in Cairo Building Research Centre to evaluate and compare the thermal comfort of a building built by traditional methods and a building built using prefabricated concrete panels. The results of the test showed a great superiority of the vernacular method regarding the indoor thermal comfort as displayed in Figure 7 (Fathy et al., 1986). The above-mentioned test shows a clear example of the effectiveness of vernacular architecture climate control methods. These results are also endorsed by Fernandes et al. (2017) who evaluated the buildings in Egypt and Portugal. 

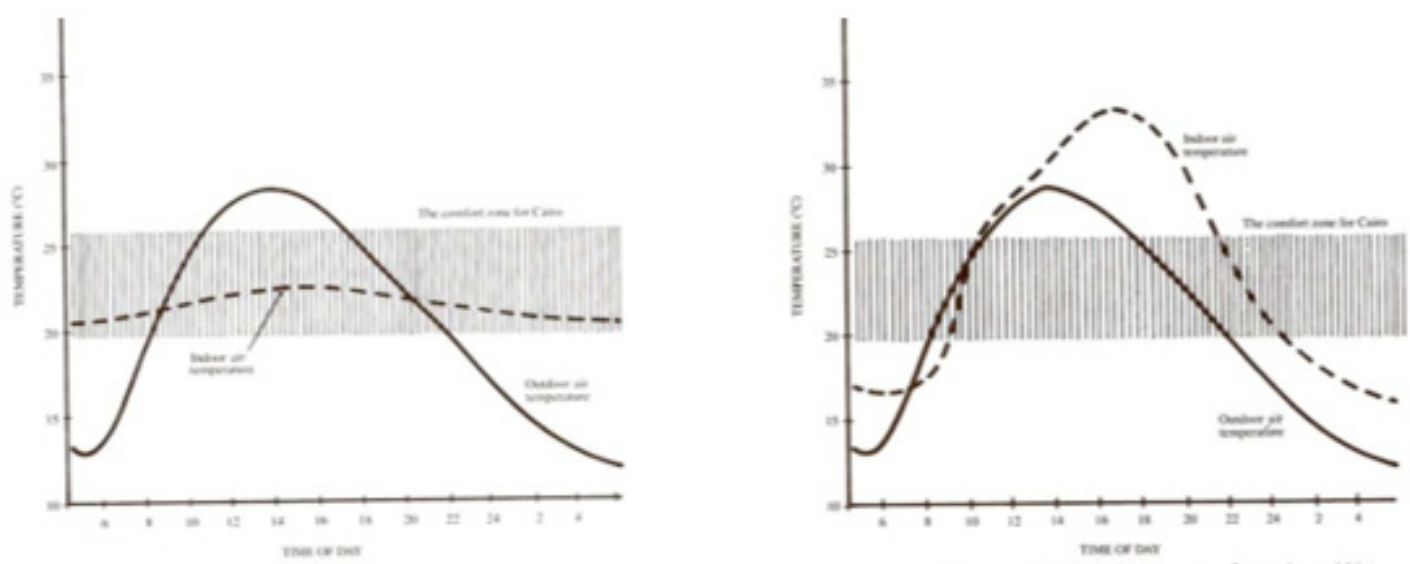

Figure 7. Comparison of the indoor air temperature between vernacular test model (on the left) and concrete test model (on the right)

\section{Conclusion}

The role of vernacular and nature to provide with sustainable solutions is not fully discovered yet. As presented in this study, a great deal of similarities is found between vernacular design qualities and nature design principles. This fact presents itself as a good chance for architects to find inspiring sustainable solutions in the vernacular. An architect is better capable to understand study and analyses examples of vernacular architecture. Moreover, the architect must also identify interesting phenomenon found in the examples present on the vernacular. The main limitations of using biomimicry in architecture is the fact that neither architects are good biologist nor biologists are good architects and bridging this gap is difficult in the present scenario. Hence, the vernomimetic approach "learning from the vernacular" has the potential to be a valid method to act as a link between nature and architecture.

\section{Acknowledgements}

The author is very thankful to all the associated personnel in any reference that contributed in/for the purpose of this research. Further, this research holds no conflict of interest and is not funded through any source.

\section{References}

Al Tawayha, F., Braganca, L., \& Mateus, R. (2019). Contribution of the Vernacular Architecture to the Sustainability: A Comparative Study between the Contemporary Areas and the Old Quarter of a Mediterranean City. Sustainability, 11(3), 896. https://doi.org/10.3390/su11030896

Amer, N. (2019). Biomimetic Approach in Architectural Education: Case study of 'Biomimicry in Architecture'Course. Ain Shams Engineering Journal. https://doi.org/10.1016/j.asej.2018.11.005

Amos Rapoport. (2006). Vernacular Design as a Model System. In L. Asquith, \& M. Vellinga (Ed.), Vernacular Architecture in the Twenty-First Century: Theory, Education and Practice (pp. 179-198). UK: Taylor and Francis.

Anderson, S., \& Dieste, E. (2004). Eladio Dieste: innovation in structural art. Princeton Architectural Press.

Berkebile, B., \& Jason, M. (2004). The living building: biomimicry in architecture, integrating technology with nature. BioInspire Magazine, 18.

Blok, V., \& Gremmen, B. (2016). Ecological innovation: Biomimicry as a new way of thinking and acting ecologically. Journal of Agricultural and Environmental Ethics, 29(2), 203-217. https://doi.org/10.1007/s10806-015-9596-1

Brown, R. (1845). Sacred Architecture, its rise, progress and present state, embracing the babylonian, indian, egyptian, greek and roman temples-the byzantine, saxon, lombard, norman and italian churches... illustrated with sixty-three plates. Fisher.

Cossins, A. R., \& Bowler, K. (1987). Rate compensations and capacity adaptations. In Temperature biology of animals (pp. 155-203). Springer, Dordrecht. https://doi.org/10.1007/978-94-009-3127-5_5 
Creswell, J. W., \& Creswell, J. D. (2017). Research design: Qualitative, quantitative, and mixed methods approaches. Sage publications.

DebRoy, T., Wei, H. L., Zuback, J. S., Mukherjee, T., Elmer, J. W., Milewski, J. O., \& Zhang, W. (2018). Additive manufacturing of metallic components-process, structure and properties. Progress in Materials Science, 92, 112-224. https://doi.org/10.1016/j.pmatsci.2017.10.001

El-Borombaly, H., \& Molina-Prieto, L. F. (2015). Adaptation of Vernacular Designs for Contemporary Sustainable Architecture in Middle East and Neotropical Region. International Journal of Computer Science and Information Technology Research, 3(4), 13-26.

Fathy, H. (1986). Natural energy and vernacular architecture. The university of Chicago Press, Chicago.

Fernandes, J. E. P., Debaieh, M., Mateus, R., Silva, S. M., Bragança, L., \& Gervásio, H. M. S. (2017). Thermal performance and comfort of vernacular earthen buildings in Egypt and Portugal. In Vernacular and Earthen Architecture: Conservation and Sustainability Proceedings of SosTierra 2017 (pp. 95-100). CRC Press. https://doi.org/10.1201/9781315267739-16

Fisher, S. (2015). Philosophy of architecture. Retrieved from https://plato.stanford.edu/entries/architecture/

Foltz, R. C. (2003). Worldviews, religion, and the environment. Thompson Wadsworth: Belmont, California.

Friedrich, C. M. (2016). A model qualification method for mechanistic physiological QSP models to support model - informed drug development. CPT: pharmacometrics and systems pharmacology, 5(2), 43-53. https://doi.org/10.1002/psp4.12056

Gosline, J. (2005). Efficiency and other criteria for evaluating the quality of structural biomaterials in Efficiency and economy in animal physiology. Cambridge University Press.

Gruber, P. (2011). Biomimetics in architecture [Architekturbionik]. In Biomimetics--Materials, Structures and Processes (pp. 127-148). Springer, Berlin, Heidelberg. https://doi.org/10.1007/978-3-642-11934-7_7

Hamard, E., Cazacliu, B., Razakamanantsoa, A., \& Morel, J. C. (2016). Cob, a vernacular earth construction process in the context of modern sustainable building. Building and environment, 106, 103-119. https://doi.org/10.1016/j.buildenv.2016.06.009

Harris, W. V. (1956). Termite mound building. Insectes sociaux, 3(2), 261-268. https://doi.org/10.1007/BF02224306

Kahn, P. H. (2011). Technological nature: Adaptation and the future of human life. MIT Press. https://doi.org/10.7551/mitpress/7983.001.0001

Korb, J., \& Linsenmair, K. E. (2000). Ventilation of termite mounds: new results require a new model. Behavioral Ecology, 11(5), 486-494. https://doi.org/10.1093/beheco/11.5.486

Lin, A., \& Meyers, M. A. (2005). Growth and structure in abalone shell. Materials Science and Engineering: A, 390, 1-2, 27-41. https://doi.org/10.1016/j.msea.2004.06.072

López, M., Rubio, R., Martín, S., \& Croxford, B. (2017). How plants inspire façades. From plants to architecture: Biomimetic principles for the development of adaptive architectural envelopes. Renewable and Sustainable Energy Reviews, 67, 692-703. https://doi.org/10.1016/j.rser.2016.09.018

Michael, A., Heracleous, C., Thravalou, S., \& Philokyprou, M. (2017). Lighting performance of urban vernacular architecture in the East-Mediterranean area: field study and simulation analysis. Indoor and Built Environment, 26(4), 471-487. https://doi.org/10.1177/1420326X15621613

Morris, M. (2005). Vitruvius: The Ten Books on Architecture. Kessinger Publishing.

Mosque Gallary. (2016). Yaama Mosque in Yaama - Niger. Retrieved from https://www.beautifulmosque.com/Yaama-Mosque-in-Yaama-Niger

Nachtigall, W. (2013). Vorbild Natur: Bionik-Design für funktionelles Gestalten. Springer-Verlag.

Oliver, P. (2006). Built to meet needs. Cultural Issues in Vernacular Architecture. https://doi.org/10.4324/9780080476308

Özkan, S. (2006). Traditionalism and vernacular architecture in the twenty-first century. In Vernacular Architecture in the 21st Century (pp. 115-127). Taylor and Francis.

Pankina, M., \& Zakharova, S. (2015). The Need for Ecologization of Design-Education. Procedia-Social and Behavioral Sciences, 214, 338-343. https://doi.org/10.1016/j.sbspro.2015.11.656 
Pawlyn, M. (2011). Biomimicry in architecture. London: Riba Publishing.

Radoine, H. (2017). Contemporary Arabic Architecture: A Quest For a Sense of Regionalism. Hespéris-Tamuda, 52(3), 377-404.

Santamouris, M., \& Francis, A. (1998). Natural ventilation in buildings: a design handbook. James and James (Science Publishers) Ltd.

Sijpkes, P. (2014). The Guastavino Family: Medieval Techniques Adapted to the Modern Context. McGill School of Architecture.

Singh, S. K. (2016). Sustainable development: A literature review. The International Journal of Indian Psychology, 6, 63-69.

Smith, J. L., \& Rust, M. K. (1994). Temperature preferences of the western subterranean termite, Reticulitermes hesperus Banks. Journal of arid environments, 28(4), 313-323. https://doi.org/10.1016/S0140-1963(05)80051-5

Solomon, E. P., Berg, L. R., \& Martin, D. W. (2005). Kingdoms or Domains? Biology (7th ed.). Belmont: Brooks/Cole Thompson Learning.

The Aga Khan Award for Architecture. (1986). Yaama Mosque. Retrieved August 1, 2012, from http://www.akdn.org/architecture/project.asp?id=550

Toates, F. M. (2007). Biological psychology. Pearson Education.

Turner, J. S., \& Soar, R. C. (2008). Beyond biomimicry: What termites can tell us about realizing the living building. In First International Conference on Industrialized, Intelligent Construction at Loughborough University (pp. 1-18).

UN. (2012). The Johannesburg Declaration on Sustainable Development. Retrieved March 1, 2012, from http://www.johannesburgsummit.org/html/documents/summit_docs/1009wssd_pol_declaration.htm

Vellinga, M. (2006). Engaging the future: Vernacular architecture studies in the twenty-first century. In Vernacular Architecture in the 21st Century (pp. 99-112). Taylor and Francis.

Vellinga, M. (2017). A Conversation with Architects: Paul Oliver and the Anthropology of Shelter. Architectural Theory Review, 2l(1), 9-26. https://doi.org/10.1080/13264826.2016.1256332

Vincent, J. F. V., \& Paul, O. (1986). Mechanical design of hedgehog spines and porcupine quills. Journal of Zoology, 210(1), 55-75. https://doi.org/10.1111/j.1469-7998.1986.tb03620.x

Wegst, U. G., Bai, H., Saiz, E., Tomsia, A. P., \& Ritchie, R. O. (2015). Bioinspired structural materials. Nature materials, 14(1), 23. https://doi.org/10.1038/nmat4089

Wilson, E. (1984). Biophilia Harvard university press. Cambridge, Massachusetts.

Zillante, G., Pullen, S., Wilson, L., Davidson, K., Chileshe, N., Zuo, J., \& Arman, M. (2013). Integrating affordable housing and sustainable housing: bridging two merit goods in Australia, Industrialised, Integrated, Intelligent Construction, 2.

\section{Copyrights}

Copyright for this article is retained by the author(s), with first publication rights granted to the journal.

This is an open-access article distributed under the terms and conditions of the Creative Commons Attribution license (http://creativecommons.org/licenses/by/4.0/). 